\title{
Identification of a Functional Receptor for Granulocyte Colony-stimulating Factor on Platelets
}

\author{
Kazuya Shimoda, ** Seiichi Okamura, * Naoki Harada, * Seiji Kondo, * Takashi Okamura, ${ }^{\star}$ and Yoshiyuki Niho \\ ${ }^{*}$ Cancer Center and the ${ }^{\ddagger}$ First Department of Internal Medicine, Faculty of Medicine, Kyushu University, Fukuoka 812, Japan
}

\begin{abstract}
Since granulocyte colony-stimulating factor (G-CSF) is thought to be a granulocyte lineage-specific cytokine, G-CSF receptors on blood cells other than those of granulocyte or monocyte lineage have not been well investigated. We now report that G-CSF receptors are present on platelets. The expression of G-CSF receptors on platelets was demonstrated by flow cytometry and radioreceptor assay. The mean number of $\mathbf{G}$ CSF-binding sites per cell was 41 and the binding affinity was high ( $K d 300$ pM), similar to the affinity observed on granulocytes. Cross-linking assay reveaied that G-CSF receptors were present on a single subunit protein of approximately $150 \mathrm{kD}$ on the platelets. To clarify whether or not G-CSF might produce some direct functional influence on platelet response, the effects on platelet aggregation were studied. Although G-CSF itself did not affect platelet aggregation in vitro, preincubation with G-CSF augmented a secondary aggregation of platelets induced by low concentrations of adenosine diphosphate (ADP). There was a dose-response relationship for this GCSF activity at concentrations of up to $10 \mathrm{ng} / \mathrm{ml}$. Furthermore, the augmented ADP-induced secondary aggregation of platelets on G-CSF receptors was completely abrogated in the presence of anti-G-CSF polyclonal antibodies. These results indicate that platelets possess functional G-CSF receptors. ( $J$. Clin. Invest. 1993. 91:1310-1313.) Key words: cytokine • flow cytometry • aggregation • adenosine diphosphate
\end{abstract}

\section{Introduction}

Granulocyte colony-stimulating factor (G-CSF) is one of the cytokines that regulate hematopoiesis $(1,2)$. It is well known that G-CSF stimulates the proliferation of those precursor cells specific to granulocytic lineage (3) and augments the functional activities of granulocytes (4-7). Since the action of GCSF is mediated by a specific G-CSF receptor, investigations concerning the surface G-CSF receptors of hematopoietic cells have been widely carried out. Although high affinity G-CSF receptor has been demonstrated on blood cells such as granulocytes $(8,9)$, monocytes $(8)$, and myeloid leukemia cells (1012), G-CSF receptor on platelets has not been hitherto documented. We herein report not only that platelets possess high

Address reprint requests to Dr. Seiichi Okamura, Cancer Center, Faculty of Medicine, Kyushu University, 3-1-1 Maidashi, Higashi-ku, Fukuoka 812, Japan.

Received for publication 11 June 1992 and in revised form 30 October 1992.

J. Clin. Invest.

(C) The American Society for Clinical Investigation, Inc.

$0021-9738 / 93 / 04 / 1310 / 04 \$ 2.00$

Volume 91, April 1993, 1310-1313 affinity G-CSF receptors, as demonstrated both by flow cytometry and by radioreceptor assay techniques, but also that G-CSF is able to alter the aggregation response of platelets.

\section{Methods}

Platelets. We obtained peripheral blood from five healthy volunteers and added 0.1 volume of citrate as the anticoagulant. The citrated peripheral blood was spun for $10 \mathrm{~min}$ at $1,000 \mathrm{~g}$, and platelet-rich plasma (PRP) ${ }^{1}$ was obtained. After centrifugation of PRP at $1,400 \mathrm{~g}$ for $10 \mathrm{~min}$, platelet-poor plasma was removed, and the platelets were then resuspended in platelet washing buffer $\left(9 \mathrm{mM} \mathrm{Na} \mathrm{NaDTA}_{2}, 26.4\right.$ $\mathrm{mM} \mathrm{Na}{ }_{2} \mathrm{HPO}_{4} \cdot 2 \mathrm{H}_{2} \mathrm{O}, 140 \mathrm{mM} \mathrm{NaCl}, \mathrm{pH} 7.2$ ) for further use. The platelet and white blood cell numbers were counted using an electric hemocytometer, Celltac (Nihon Kohden, Tokyo, Japan). The contamination with white blood cells was less than 1 cell per 1,000 platelets.

Flow cytometry. We have developed a fluorescence method for the detection of G-CSF receptors (13). Briefly, G-CSF (Kirin Breweries, Tokyo, Japan) reacted with biotinyl $N$-hydroxy succinimide ester (EOY LABS, San Mateo, CA) to yield biotinylated G-CSF (b-G-CSF), and this b-G-CSF retained sufficient ability to stimulate colony formation by normal bone marrow cells in methylcellulose. Platelets were resuspended in reaction buffer (Dulbecco's $\mathrm{Ca}^{++} \mathrm{Mg}^{++}$-free phosphate-buffered saline containing $0.1 \%$ BSA and $0.1 \%$ sodium azide). 1 $\times 10^{6}$ platelets were incubated with $145 \mathrm{ng}$ of b-G-CSF in $100 \mu \mathrm{l}$ of binding buffer for $30 \mathrm{~min}$ at $24^{\circ} \mathrm{C}$. As controls, either the binding buffer alone or b-G-CSF in the presence of a 100 -fold excess of unlabeled G-CSF was added instead of b-G-CSF. After being washed three times with reaction buffer, 50 ng of streptavidin-PE (Becton Dickinson, Mountain View, CA) were added to the pellets. This mixture was then incubated for $30 \mathrm{~min}$ at $4^{\circ} \mathrm{C}$. We set the analysis window on the platelet area according to the forward light scatter and side light scatter and performed the fluorescence analysis using a FACScan ${ }^{\otimes}$ (BectonDickinson). Platelets in this window were positive for both CD41b (TP80; Nichirei, Tokyo) and CD42b (Human platelet GPIb; Takara Syuzou, Tokyo).

Radioreceptor assay. Radioreceptor assay for G-CSF using ${ }^{125} \mathrm{I}$-labeled G-CSF has been described by us elsewhere (10). Briefly, platelets $\left(6 \times 10^{6}\right)$ in $200 \mu \mathrm{l}$ of reacting buffer (Iscove's modified Dulbecco medium with $0.2 \%$ BSA) containing various concentrations of ${ }^{125} \mathrm{I}-\mathrm{G}$ CSF, either with or without a 100 -fold excess of unlabeled G-CSF, were incubated for $2 \mathrm{~h}$ at $24^{\circ} \mathrm{C}$. The specific binding was determined from the amount of binding blocked by competition with a 100 -fold excess of unlabeled G-CSF. The data from the binding experiments were analyzed by the method of Scatchard.

Cross-linking of ${ }^{125} \mathrm{I}-\mathrm{G}$-CSF to its receptors. ${ }^{125} \mathrm{I}-\mathrm{G}-\mathrm{CSF}$ at $300 \mathrm{pM}$ was incubated with $3 \times 10^{8}$ platelets in $1 \mathrm{ml}$ of binding buffer in the presence or absence of a 100 -fold excess of unlabeled G-CSF for $2 \mathrm{~h}$ at room temperature. After the incubation, chemical cross-linking experiments were performed using reported methods (9). The cell pellet was resuspended in $0.5 \mathrm{ml}$ of cold PBS and incubated with disuccinimidyl suberate (DSS, Pierce Chemical Co., Rockford, IL) (final concentration of DSS, $0.9 \mathrm{mM}$ ) at $4^{\circ} \mathrm{C}$ for $15 \mathrm{~min}$. The reaction was quenched by

1. Abbreviations used in this paper: b-G-CSF, biotinylated G-CSF; PRP, platelet rich plasma. 
adding $1 \mathrm{ml}$ of cold Tris- $\mathrm{HCl}$ buffer ( $10 \mathrm{mM}$, pH 7.4) with $1 \mathrm{mM}$ EDTA. The tubes were centrifuged, and the resultant cell pellet was solubilized in $40 \mu \mathrm{l}$ of $25 \mathrm{mM}$ Tris- $\mathrm{HCl}$ buffer ( $\mathrm{pH} \mathrm{7.4)} \mathrm{containing} 1 \%$ Triton X-100 and $1 \mathrm{mM}$ phenylmethylsulfonylfluoride (Sigma Chemical Co., St. Louis, MO). After $10 \mathrm{~min}$ of incubation on ice, the tubes were centrifuged at $15,000 \mathrm{~g}$ for $10 \mathrm{~min}$ at $4^{\circ} \mathrm{C}$. The extracted cell surface proteins were mixed with $20 \mu \mathrm{l}$ of two-fold concentrated Laemmli's sample buffer and then boiled for $5 \mathrm{~min}$. The sample was loaded onto $8 \%$ polyacrylamide $/ \mathrm{NaDodSO}_{4}$ gels. The gels were stained ( $50 \%$ trichloroacetic acid, $0.1 \%$ Coomassie blue), destained ( $7 \%$ acetic acid), dried, and then autoradiographed using an Imaging Analyzer (BAS system, Fuji Film, Tokyo, Japan).

Measurement of platelets aggregation. Several concentrations of G-CSF in $5 \mu \mathrm{l}$ of $0.004 \%$ tween $80,5 \%$ mannitol, $10 \mathrm{mM}$ acetate buffer, pH 4.0 or solvent alone were added to $200 \mu \mathrm{l}$ of PRP, $15 \mathrm{~min}$ prior to the addition of adenosine diphosphate (ADP $1.5 \mu \mathrm{M}$ ). The aggregation of platelets was measured using an NBS HEMATRACER 6 (Nikou Bioscience, Tokyo, Japan) maintaining the cuvette temperature at $37^{\circ} \mathrm{C}$ and the stirring speed at $1,000 \mathrm{rpm}$.

Blocking assay was performed using IgG purified from rabbit antihuman rG-CSF polyclonal antibodies (14). This polyclonal antibody against rG-CSF completely inhibited the in vitro colony formation of bone marrow cells induced by G-CSF (14). Either solvent alone, 10 $\mathrm{ng} / \mathrm{ml} \mathrm{G}-\mathrm{CSF}$ plus $2 \mu \mathrm{g} / \mathrm{ml}$ rabbit preimmune $\mathrm{IgG}, 10 \mathrm{ng} / \mathrm{ml} \mathrm{G}-\mathrm{CSF}$ plus $2 \mu \mathrm{g} / \mathrm{ml}$ rabbit polyclonal antibodies against G-CSF, or $2 \mu \mathrm{g} / \mathrm{ml}$ rabbit polyclonal antibodies against G-CSF was added to PRP, and the platelet aggregation induced by ADP was measured as described above.

\section{Results}

The expression of G-CSF receptors on platelets was determined by flow cytometry (Fig. $1 A$ ). Platelets reacted with b-G-CSF and streptavidin-conjugated PE and showed specific fluorescence to both b-G-CSF and streptavidin-PE, which was completely abrogated in the presence of a 100 -fold excess of unlabeled G-CSF. This shift indicates the specific binding of b-G-CSF to platelets. The G-CSF receptors present on platelets were characterized by radioreceptor assay using radioiodinated human rG-CSF (Fig. $1 \mathrm{~B}$ ). When the specific binding data were replotted by the method of Scatchard, a primary regression line was established by calculation, using the least-squares method. The mean \pm SD (range) number of G-CSF binding sites per platelet from five volunteers was $41 \pm 7$ (37-50), and the binding affinity was high $[K \mathrm{~d} 300 \pm 150(277-558) \mathrm{pM}]$.

Following the binding experiments, cross-linking studies of G-CSF receptors, using the homobifunctional agent DSS, were performed. As shown in Fig. 2, only one major band (170 kD), possibly corresponding to the ${ }^{125} \mathrm{I}-\mathrm{G}-\mathrm{CSF}$ receptor complex, was detected under reducing conditions. This band disappeared completely when the binding was performed in the presence of a 100 -fold excess of unlabeled G-CSF, indicating that one species of about $150 \mathrm{kD}$ was one type of component of the specific receptor for G-CSF, since ${ }^{125}$ I-G-CSF has an approximate molecular mass of $20 \mathrm{kD}$.

Investigations were then extended to find out whether or not G-CSF might show some direct influence on in vitro platelet responses using PRP from five volunteers. Although G-CSF itself did not affect platelet aggregation in vitro when added to PRP (data not shown), preincubation with G-CSF altered the aggregation response of platelets to ADP. G-CSF at concentrations as low as $0.1 \mathrm{ng} / \mathrm{ml}$ substantially enhanced the response and produced a secondary aggregation of platelets induced by ADP (Fig. $3 A$ ). There was a dose-response relationship for this G-CSF activity at concentrations of up to $10 \mathrm{ng} / \mathrm{ml}$.

\section{A}

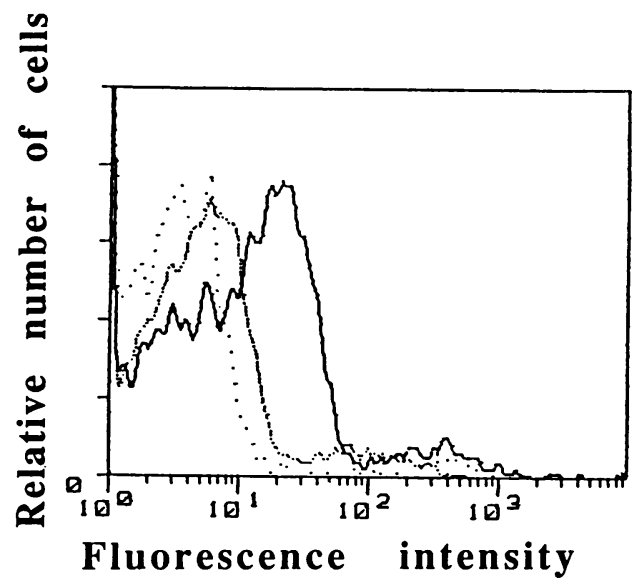

B

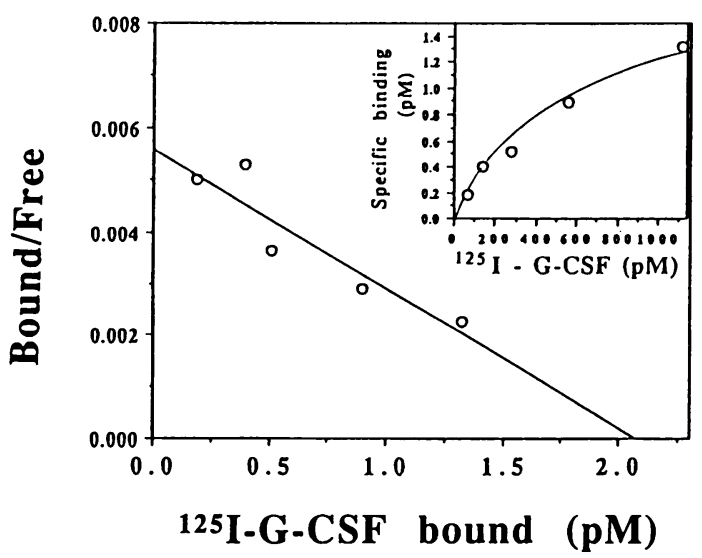

Figure 1. The expression of G-CSF receptors on platelets by flow cytometry $(A)$ and radioreceptor assay $(B) .(A)$ Platelets were incubated with either b-G-CSF $(-)$, buffer only $(\cdots)$, or b-G-CSF in the presence of a 100-fold molar excess of unlabeled G-CSF (- - - - - ). After being washed, streptavidin-PE was added. Abscissas indicate fluorescence intensity, which reflects the amount of labeled G-CSF and streptavidin-PE. A high fluorescence signal is shown by a solid line, which was abrogated in the presence of a 100 -fold molar excess of unlabeled G-CSF. $(B)$ Platelets in binding buffer containing various concentrations of ${ }^{125} \mathrm{I}-\mathrm{G}-\mathrm{CSF}$, either with or without a 100 fold excess of unlabeled G-CSF, were incubated. The specific binding was determined from the amount of binding blocked by competition with a 100 -fold excess of unlabeled G-CSF.

Blocking assay was performed using rabbit anti-human GCSF polyclonal antibodies (IgG). The augmented ADP-induced secondary aggregation of platelets by G-CSF was completely abrogated in the presence of anti-G-CSF polyclonal antibodies (Fig. $3 \mathrm{~B}$ ), (2), whereas it was not affected in the presence of preimmune rabbit IgG (Fig. $3 B$ ) (1). Rabbit antiG-CSF polyclonal antibodies alone ( Fig. $3 B$ ), (3) did not have any influence on the ADP-induced secondary aggregation of platelets.

\section{Discussion}

Since G-CSF is thought to be a granulocyte lineage-specific cytokine (3), G-CSF receptors on blood cells other than those 


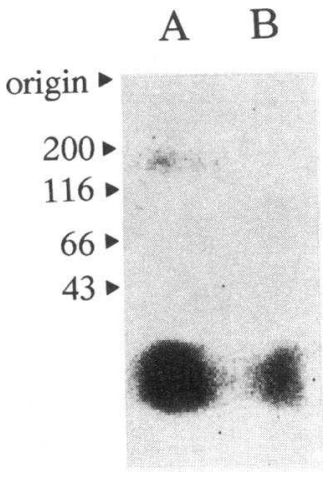

Figure 2. Cross-linking of ${ }^{125} \mathrm{I}-\mathrm{G}-\mathrm{CSF}$ to platelets. Binding was performed at $24^{\circ} \mathrm{C}$ for $2 \mathrm{~h}$ in the absence (lane $A$ ) or presence (lane $B$ ) of excess unlabeled G-CSF. After the cross-linking reaction, detergent-soluble extracts of platelets were analyzed by gradient SDS-PAGE under reducing conditions.

of granulocyte or monocyte lineage have not been well investigated. We then investigated G-CSF receptors on platelets.

The expression of G-CSF receptors on platelets was demonstrated by flow cytometry (Fig. $1 \mathrm{~A}$ ) and radioreceptor assay (Fig. $1 B$ ). The number of G-CSF receptors on platelets was $41 \pm 7$, and the binding affinity was high $(K \mathrm{~d} 300 \pm 150 \mathrm{pM})$. $\mathrm{G}-\mathrm{CSF}$ receptors on human granulocytes showed similar $\mathrm{Kd}$ $(350 \pm 90)$, but with larger numbers of binding sites $(412 \pm 158)$. The contamination with white blood cells was below 1 cell per 1,000 platelets among the platelet samples. Since the G-CSF receptors on neutrophils were $412 \pm 158$ per cell, and since those were not detected on lymphocytes, the effect of contaminated neutrophils on G-CSF binding sites per platelet was less than 0.4 per platelet. We can therefore exclude the possible influence of contaminated neutrophils from the platelet samples. Moreover a cross-linking assay revealed that GCSF receptors were present on a single subunit protein of approximately $150 \mathrm{kD}$ on the platelets (Fig. 2). The molecular size of the G-CSF receptor on the platelets was the same as that previously reported on granulocytes (9).

To clarify whether or not G-CSF might have some direct functional influence on platelets, platelet aggregation was studied. Preincubation with G-CSF altered the aggregation response of platelets to ADP. This priming effect was achieved at G-CSF concentrations as low as $0.1 \mathrm{ng} / \mathrm{ml}$, and there was a dose-response relationship at concentrations of up to $10 \mathrm{ng} / \mathrm{ml}$

A

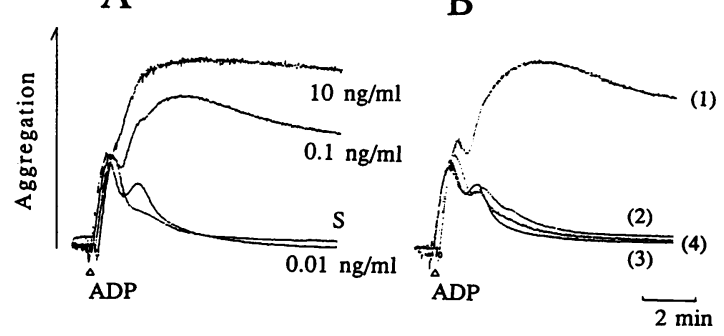

Figure 3. Effect of G-CSF on ADP-induced aggregation in human PRP. ( $A$ ) PRP was preincubated with various concentrations of GCSF or solvent alone $(S)$ for 15 min prior to the addition of ADP ( 1.5 $\mu \mathrm{M})$. (B) The effect of anti-G-CSF antibody on ADP-induced secondary aggregations of platelets. Either $10 \mathrm{ng} / \mathrm{ml} \mathrm{G-CSF}$ plus $2 \mu \mathrm{g} / \mathrm{ml}$ rabbit preimmune IgG (1), $10 \mathrm{ng} / \mathrm{ml}$ G-CSF plus $2 \mu \mathrm{g} / \mathrm{ml}$ rabbit polyclonal antibodies against rG-CSF (2), $2 \mu \mathrm{g} / \mathrm{ml}$ rabbit polyclonal antibodies against $r$ G-CSF alone (3), or solvent alone (4) was added to PRP, and the platelet aggregation induced by $\operatorname{ADP}(1.5 \mu \mathrm{M})$ was measured.
(Fig. $3 \mathrm{~A}$ ). Such concentrations of G-CSF are sometimes observed in patients with bacterial infections and could easily be reached during clinical G-CSF administration $(15,16)$. This priming effect of G-CSF on platelets to induce secondary aggregation by ADP is similar to that of mature granulocytes to release oxygen radicals (4). Although GM-CSF also has a priming effect on mature granulocytes $(17,18)$, preincubation with GM-CSF at concentrations of from 0.1 to $1,000 \mathrm{ng} / \mathrm{ml}$ did not alter the response of platelets to ADP (data not shown).

The target cells of G-CSF have been considered to be committed granulocyte precursor cells as well as cells of neutrophil lineage at various stages of maturity $(19,20)$. However, evidence that G-CSF works not only on committed neutrophil precursors but also on more immature multipotent cells has been accumulating (21-23). For example, G-CSF shortens the period of chemotherapy-induced bone marrow hypoplasia (21), increases the total number of colony-forming cells (22), and increases the percentage of actively cycling cells in the marrow (22). Furthermore, G-CSF acts synergistically with IL-3 in shortening the $G_{0}$ period of cells forming immature multipotent blast colonies (23). Even though this is the first report showing that mature platelets possess G-CSF receptors, Lindemann et al. (24) reported that in vivo administration of higher G-CSF doses affected platelet numbers. They observed a dose-dependent depression of platelet counts after intravenous administration of G-CSF (24). The discovery that G-CSF exerts influence on mature platelets and alters the aggregation response to ADP would confirm the presence of G-CSF receptors on platelets.

\section{Acknowledgments}

We are grateful to Dr. W. Ikematsu, Dr. H. Tsuda, and Dr. S. Inaba for valuable advice, and to $\mathrm{H}$. Baba and $\mathrm{K}$. Fukuchi for their excellent technical assistance. In addition, we wish to thank Miss $\mathrm{K}$. Miller (Royal English Language Centre) for proofreading this manuscript.

This work was supported in part by grants-in-aid from the Ministry of Education, Science, and Culture of Japan (04247102, 044545-72, 02256102, 03252102 and 03670325). The authors thank Kirin Breweries Co. Ltd. (Tokyo, Japan) for providing rG-CSF.

\section{References}

1. Burgess, A. W., and D. Metcalf. 1980. The nature and action of granulocyte-macrophage colony-stimulating factors. Blood. 56:947-958.

2. Metcalf, D. 1986. The molecular biology and functions of granulocyte-macrophage colony-stimulating factors. Blood. 67:257-267.

3. Souza, L. M., T. C. Boone, J. Gabrilove, P. H. Lai, K. M. Zsebo, D. C. Murdock, V. R. Chazin, J. L. H. Bruszewski, K. K. Chen, J. Barendt, E. Platzer, M. A. S. Moore, and R. Mertelsmann. 1986. Recombinant human granulocyte colony-stimulating factor. Effects on normal and leukemic myeloid cells. Science (Wash. DC). 232:61-65.

4. Kitagawa, S., A. Yuo, L. M. Souza, M. Saito, Y. Miura, and F. Takaku. 1987. Recombinant human granulocyte colony-stimulating factor enhances superoxide release in human granulocyte stimulated by the chemotactic peptide. Biochem. Biophys. Res. Commun. 144:1143-1146.

5. Clark, S. C. 1988. Biological activities of human granulocyte-macrophage colony-stimulating factor. Int. J. Cell Cloning. 6:365-377.

6. Kondo, S., S. Okamura, N. Ohhara, and Y. Niho. 1990. Direct action of human granulocyte colony-stimulating factor on mature human neutrophils: Flow-cytometric analysis. Res. Commun. Chem. Pathol. Pharmacol. 67:249257.

7. Wang, J. W., Z. G. Chen, S. Colella, M. A. Bonilla, and K. Welte. 1988. Chemotactic activity of recombinant human granulocyte colony-stimulating factor. Blood. 72:1456-1460.

8. Nicola, N. A., and D. Metcalf. 1985. Binding of ${ }^{125} \mathrm{I}$-labeled granulocyte colony-stimulating factor to normal murine hemopoietic cells. J. Cell. Physiol. 124:313-321. 
9. Uzumaki, H., T. Okabe, N. Sasaki, K. Hagiwara, F. Takaku, and S. Itoh 1988. Characterization of receptor for granulocyte colony-stimulating factor on human circulating neutrophils. Biochem. Biophys. Res. Commun. 156:10261032.

10. Kondo, S., S. Okamura, Y. Asano, M. Harada, and Y. Niho. 1991. Human granulocyte colony-stimulating factor receptors in acute myelogenous leukemia. Eur. J. Haematol. 46:223-230.

11. Budel, L. M., I. P. Touw, R. Delwel, and B. Lowenberg. 1989. Granulocyte colony-stimulating factor receptors in human acute myelocytic leukemia. Blood. 74:2668-2673.

12. Piao, Y. F., and T. Okabe. 1990. Receptor binding of human granulocyte colony-stimulating factor to the blast cells of myeloid leukemia. Cancer Res. 50:1671-1674.

13. Shimoda, K., S. Okamura, N. Harada, and Y. Niho. 1992. Detection of the granulocyte colony-stimulating factor receptor using biotinylated granulocyte colony-stimulating factor: presence of granulocyte colony-stimulating factor receptor on CD34-positive hematopoietic progenitor cells. Res. Exp. Med. 192:245-255

14. Shimoda, K., S. Okamura, F. Omori, Y. Mizuno, T. Hara, T. Aoki, K. Ueda, and Y. Niho. 1991. Granulocyte colony-stimulating factor in cerebrospinal fluid from patients with meningitis. Blood. 77:2214-2217.

15. Watari, K., S. Asano, N. Shirafuji, H. Kondo, K. Ozawa, F. Takaku, and S. Kamachi. 1989. Serum granulocyte colony-stimulating factor levels in healthy volunteers and patients with various disorders as estimated by enzyme immunoassay. Blood. 73:117-122.

16. Kawakami, M., H. Tsutsumi, T. Kumakawa, H. Abe, M. Hirai, S. Kurosawa, M. Mori, and M. Fukushima. 1990. Levels of serum granulocyte colonystimulating factor in patients with infections. Blood. 76:1962-1964.
17. Yuo, K., S. Kitagawa, A. Ohsaka, M. Saito, and F. Takaku. 1990. Stimulation and priming of human neutrophils by granulocyte colony-stimulating factor: Qualitative and quantitative differences. Biochem. Biophys. Res. Commun. 171:491-497.

18. Yamaga, S., S. Okamura, T. Otsuka, and Y. Niho. 1989. Effect of granulocyte-macrophage colony-stimulating factor on chemiluminescence of human neutrophils. Int. J. Cell Cloning. 7:50-58.

19. Clark, S. C., and R. Kamen. 1987. The human hematopoietic colony-stimulating factors. Science (Wash. DC). 236:1229-1237.

20. Sieff, C. A. Hematopoietic growth factors. 1990. J. Clin. Invest. 79:15491557.

21. Welte, K., M. A. Bonilla, A. P. Gillio, T. C. Boone, G. K. Potter, J. L. Gabrilove, M. A. S. Moore, R. J. O'Reilly, and L. M. Souza. 1987. Recombinant human granulocyte colony-stimulating factor. Effects on hematopoiesis in normal and cyclophosphamide-treated primates. J. Exp. Med. 165:941-948.

22. Cohen, A. M., M. Z. Krisztina, H. Inoue, D. Hines, T. C. Boone, V. R. Chazin, L. Tsai, T. Ritch, and L. M. Souza. 1987. In vivo stimulation of granulopoiesis by recombinant human granulocyte colony-stimulating factor. Proc. Natl. Acad. Sci. USA. 84:2484-2488.

23. Ikebuchi, K., S. C. Clark, J. N. Ihle, L. M. Souza, and M. Ogawa. 1988. Granulocyte colony-stimulating factor enhances interleukin-3-dependent proliferation of multipotential hemopoietic progenitors. Proc. Natl. Acad. Sci. USA 85:3445-3449.

24. Lindemann, A., F. Herrmann, W. Oster, G. Haffner, W. Meyenburg, L. M. Sooza, and R. Mertelsmann. 1989. Hematopoietic effects of recombinant human granulocyte colony-stimulating factor in patients with malignancy. Blood. 74:2644-2651. 